\section{Towards European Union or Regional Economic Area: Western Balkans at Crossroads}

\author{
Gazmend Qorraj \\ Faculty of Economics, University of Prishtina, Kosovo \\ gazmendqorraj@yahoo.com
}

\begin{abstract}
The aim of the paper is to reflect upon the dilemma or whether the EU will continue the integration process in the Western Balkans or backlash on regional cooperation instruments and initiatives within the framework of the Western Balkans. The Regional Economic Area (REA) is analyzed as the more recent policy of the European Union for the remaining Balkan countries. It is crucial to analyze the idea behind REA, starting from two main assumptions: first, the creation of REA stemmed from EU internal challenges; and second, REA came up as a creative EU approach in efforts to find a specific model for reforms in the Western Balkans in the frame of regional institutions. The paper also discusses regional trade and specifically the role of the Regional Cooperation Council (RCC) in coordinating these initiatives in the Western Balkans. Taking into consideration the EU current challenges as well as difficulties of the Western Balkan countries to overcome the political and economic problems, then regional cooperation could appear as an alternative to the EU integration process for the Western Balkans. The main conclusion of this paper is that the Western Balkans needs the EU's direct support, in particular, since RCC and other regional instruments cannot enforce, support and monitor the initiatives and reforms in the region.
\end{abstract}

Keywords: Western Balkans, integration, cooperation, coordination, regional, enlargement

\section{Introduction}

The Western Balkan countries together make a small market in the region that depends on improved regional cooperation, EU integration processes and developments in the world markets. The regional integration of the Western Balkans represents an important aspect of European Integration for the countries of the region (Pere, 2009, p. 159). Deepening cooperation and trade between Western Balkan countries would bring both economic and political benefits to the region by reducing trade barriers, increasing foreign investments, and improving the business environment. The EU should strengthen the regional approach by giving all countries of the region tangible European commitment (Rupnik, 2010, p.7). According to Doring (1997, p.16) the initial EU accession strategy for the Western Balkans was one that linked accession to the peace of reform in the individual countries of the Western Balkans.

During 1999, the Stability Pact for the South East Europe (SEE) was created by the international community as the main institution for the regional cooperation
REVIEW PAPER

RECEIVED: NOVEMBER 2017

REVISED: FEBRUARY 2018

ACCEPTED: FEBRUARY 2018

DOI: 10.2478/ngoe-2018-0002

UDK: 339.92(497)

JEL: B22, F15, J61

Citation: Qorraj, G. (2018). Towards European Union or Regional Economic Area: Western Balkans at Crossroads. Naše gospodarstvo/Our Economy, 64(1), 11-17. DOI: 10.2478/ngoe-2018-0002

\section{NG OE}

NAŠE GOSPODARSTVO OUR ECONOMY

\begin{tabular}{l|l|l} 
Vol. 64 & No. 1 & 2018
\end{tabular}

pp. $11-17$ 
in the Western Balkans, and it was transformed in 2008 into the Regional Cooperation Council (RCC). During 2017, the EU launched the idea of the Regional Economic Area of the Western Balkans as an instrument for further integration of the region. Furthermore, the EU authorized the RCC to implement national and regional activities in four areas, such as: trade, investments, mobility and digital integration, all within the framework of the Regional Economic Area.

There is a question whether this institution, namely the RCC, can perform its role in coordinating and supporting political, economic and institutional agenda for the Western Balkans. The question gains importance when taking into consideration the political challenges, trade disputes and other problems between countries of the region. During 1999, it was necessary for the international community to set up a mechanism for regional cooperation then known as the Stability Pact, with the purpose of establishing a framework of peace and cooperation between countries in the region. Nowadays, however, its successor, the RCC, does not appear to have the prerequisites or capacity to further enhance, coordinate, or even more importantly, monitor regional initiatives in the Western Balkans.

Lessons learned from the Regional Ownership on the Western Balkans, which was launched in 2006 and implemented in 2008, teach us that regional mechanisms in the Western Balkans cannot have significant success. For illustration, the success of CEFTA implementation during 2007 depended on the EU Institutions, as the countries of the Western Balkans couldn't resolve political and trade disputes. Therefore, the role of the EU institutions and other international stakeholders appears critical because of fragile institutions in the Western Balkan region. The EU's intention to delegate the power of integration from Brussels to Sarajevo could be a message that the region of the Western Balkans will be supported indirectly by the EU. That would mean the EU will create a preferential relationship on trade and a few other key areas with the Western Balkans, with the enlargement process most likely slowing down in the meantime.

The main research question of this paper is to assess whether this initiative came as result of internal EU challenges for involvement in the Western Balkans or as a result of new understanding that regional issues in the Western Balkans can be addressed more efficiently within RCC as a regional mechanism. The paper consists of the following sections: introduction, literature review, methodology and a discussion and analysis of the main findings. The final part of the paper presents conclusions emphasizing the most important findings and value added of the paper.

\section{Methodology}

According to the various estimates and analysis carried out, at this initial stage of the REA development, it is very difficult to predict the outcomes of REA development and its future impact in the Western Balkans. An alternative route to investigating the impact of REA could be built on the existing knowledge and experiences on the functioning of regional instruments. Besides, several interviews were carried out with local experts on EU studies to better address the research questions and surveys were conducted with 100 respondents / postgraduate students to gain their views on REA and EU initiatives. The interviews and surveys focused on Prishtina: Firstly, since students of the University of Prishtina are representative of the opinion of the educated Kosovo population since they come from all sides of Kosovo; and secondly, since the central government and other institutions are based in Prishtina. The sample and region were selected in order to achieve a high rate of response as well as to ensure the quality of surveys from the respondents, in particular, keeping in mind that the Regional Economic Area (REA) is a new and specific EU initiative with few people having information about it in Kosovo.

\section{Theoretical Background}

Economic integration is considered as a form of internationalization of production within a given region (Moraliyska, 2014, p.3). Furthermore, market integration is a crucial pre-condition for further cooperation and integration between countries. Therefore, creation of free trade areas through the gradual liberalization of trade, harmonization of procedures and expansion of trade and investments in the region is seen as needed. In another perspective, Grossman and Helpman (1993, p.667) concluded that the decision of countries to conclude regional trade agreements is determined from the extent to which the government is concerned about the welfare of its constituents.

According to the Stability Pact (2001), the Central European Free Trade Agreement (CEFTA) was considered the most important free trade agreement of Central and South East European countries that included Poland, the Czech Republic, Slovakia, and Hungary, followed by Slovenia, Romania, and Bulgaria. Being the first regional economic association for these countries, it has contributed over the years to improve the trade regime and prepare its members for accession to the EU. Most of these countries, by promoting trade and cooperation, increased trade flows, strengthened economic relations, increased economic convergence and successfully joined the EU. 
On the other hand, as of 2000, the Stabilization and Association Process (SAP) launched by the EU provided all Western Balkan countries with free access to EU markets through Autonomous Trade Measures (ATMs). Autonomous Trade Measures enabled free movement of trade from the Western Balkans to the EU, therefore offering opportunities for Western Balkan countries (Štiblar, 2008, p.66). Additionally, the Central European Free Trade Agreement (CEFTA 2006) was launched by the EU for the countries of the Western Balkans to promote free trade and economic prosperity for the region. According to Tempera (2011, p.2), the CEFTA is inspired by the World Trade Organization (WTO), and as a result, the WTO strictly honors the ensuing policy created.

The CEFTA 2006, as a comprehensive free trade agreement with the aim of trade liberalization, addresses various non-tariff barriers as well as other areas such as investment, services, public procurement and intellectual property rights (Hadjinski, 2010, p.3).

The market integration and investment climate in the Western Balkans was fragile due to long-term conflict and problems from the past between the Western Balkan countries. Unfortunately, the political challenges and business environment are still constraining FDI flows in the Western Balkans. According to the World Bank, most of the Western Balkan countries specialize in low- value added products, and comparative advantage is frequent in products with medium-low or low technological intensity (World Bank, 2015). There is very low R\&D budget translated into an almost nonexistent number of deposited patents, which is seen as one of the reasons that these countries cannot benefit significantly from the EU market.

According to Kathuria (2008, p.6), intra-industry trade is also low between Western Balkans and the EU. Despite the free-trade arrangements with the EU, the share of Intra Industry Trade (IIT) is below $30 \%$ for each country apart from Croatia, which is far less compared to the share of (EU-10) prior to accession around 40\% in 2002. However, the exports remain low, as a share of GDP in Western Balkans and below potential according to the World Bank report of 2015, as exports averaged around 38\% of GDP in 2013 in WB6 countries. According to the report, Kosovo and Bosnia are experiencing low performance with exports share around $20-30 \%$ of GDP; Albanian exports to the EU are estimated at $40 \%$ below potential, while other countries are around $30 \%$ below potential. This compares with over $60 \%$ in EU 11 countries. This situation is due to higher economic differences between the EU and Western Balkans.

Despite the success story of CEFTA for the countries of Central Europe, the implementation and functioning of the CEFTA2006 for Balkans was quite complex and the economic impact was partial. Therefore, the efforts towards economic integration through the CEFTA 2006 have not increased the shares of trade within the Western Balkans at the expected levels, and the EU has remained the dominant export market for all the Western Balkans (World Bank, 2015). Due to this fact, CEFTA 2006 could serve mainly as the instrument for institutional reforms in the Western Balkans such as: rules of origin, sanitary and phytosanitary issues, non-tariff measures and other important issues, and less for the increase of the export and trade between countries.

\section{Regional cooperation}

Regional co-operation was considered as a very important instrument for the Western Balkans and an engine to pull the entire region away from the conflicts and consolidate peace and democracy (Erler, 2004, p.11). During 1999-2008 few challenges of the region were addressed, and good neighborly relations were initiated within the Stability Pact framework. Given the lack of co-operation in the Western Balkans, the intensification of regional cooperation by the European Union was crucial, as the Western Balkans needed the European agenda. The main regional initiatives between the Western Balkans achieved between 2001 and 2008 include: Energy Community, European Common Aviation Area Agreement (ECAA), MOU on South East Europe Transport Observatory (SEETO), CEFTA and Bilateral Free Trade Agreements, Stability Pact for SEE, European Charter for Small Enterprises, Investment Compact, Electronic Southeast Europe Initiative (“eSEE”), and Non-Tariff Barriers Removal Initiative (Stability Pact for South East Europe, 2008). These initiatives created short-term cooperation between the Western Balkan countries. Despite the challenges, the Western Balkan countries continued their regional cooperation to benefit economically and institutionally from the European integration process, therefore to promote local institutions and their administrative capabilities. Nowadays, the EU framework and appropriate policies in Western Balkans could also prevent further increase of Russian influence in the region and especially in Serbia and Montenegro - a kind of influence capable of generating additional challenges to cooperative efforts among the Western Balkans.

\section{Regional ownership and RCC role}

For the EU, the idea of the regional ownership was considered very important as an instrument to transfer competencies from the international community, namely the EU, to the region of the Western Balkans. Therefore, during 2008, the EU transformed the Stability Pact for SEE from Brussels to the newly formed Regional Cooperation Council 
in Sarajevo. Besides, the leadership of this mechanism was also "regionalized" from EU to leadership coming from the Western Balkans. The idea of regional ownership in the framework of regional co-operation was launched under the following assumptions (Qorraj, 2010, p.81):

- Satisfactory regional co-operation has been achieved in the Western Balkans;

- Western Balkan countries should play an active role on the regional cooperation; and

- Western Balkan countries are ready to intensify their regional cooperation process.

But the core question remains whether regional ownership is an appropriate policy or framework, taking into consideration political and economic challenges between the countries of the region, specifically the unresolved political relationship between Kosovo and Serbia. The obstacles or problems in the Western Balkans become apparent when looking at the implementation of the Regional Ownership and CEFTA 2006 during 2008. Serbia and Kosovo could not overcome political challenges, with Serbia applying barriers and trade disputes against Kosovo. Additionally, the Serbian leadership strongly opposed Kosovo's integration into regional and international institutions, making it thus impossible for Kosovo to participate in the above-mentioned regional initiatives. This was a huge setback to regional cooperation. From 2008 to 2012, the presence of Kosovo in regional initiatives and meetings was seriously challenged (Qorraj, 2016, p.196). Past experience showed that although the regional ownership was launched by the EU with the purpose to transfer the "decision making process" from the EU to the Western Balkans, despite its minor achievements, this process in the Western Balkans has failed, putting the region of the Western Balkans at yet another crossroads. With the actual initiative such as "Regional Economic Area", the region could face other numerous challenges between countries in the region under the supervision and monitoring of the Regional Cooperation Council.

\section{European integration vs. Regional Economic Area}

Juncker (2017) acknowledged that Europe faces problems, therefore he declared, "I'm not in favor of the Western Balkans joining the EU soon”. But if you take away the European perspective, then we might again experience what we experienced in the 1990s. In this respect, the stability of the composition of the European Union is a prerequisite for the Western Balkans not being at war again. From one point of view, this statement makes it clear that the EU does not see in the Western Balkans a region that could converge within the EU but, on the contrary, sees dealing with the Balkans as a measure to save the region from potential repetition of the past conflicts.
From another point of view, in the Western Balkans, there is a higher expectation of the people for the path towards the EU. Therefore, the question is whether these people have enough information about the EU challenges and on what is such optimism for the EU grounded. Bieber and Kmezić (2016, p.2) stated that the "optimism” for the EU membership in Western Balkans is due to the fact that EU integration was the main driving force for democracy and reforms, and close cooperation with the countries of Western Europe provide a model, a partner and a goal for many citizens in the region. The second important point is that people in the Western Balkans are governed by "corrupt and authoritarian” leaders, and therefore, the EU enlargement is seen as an instrument that accelerates democratic, economic and institutional reforms in their countries. Furthermore, the EU-Western Balkans Summit in Thessaloniki 2003 translated the vision for EU integration into a commitment (Schaefer, 2004, p.34).

During 2017, the EU launched the Regional Economic Area (REA) for the Western Balkans. The REA was first introduced as the "Western Balkans Common Market" within the framework of the Berlin Process, followed by the Trieste Summit in July 2017, with involvement of the EU and Western Balkan leaders. According to the (DG NEAR of the European Commission, 2017), the creation of a Regional Economic Area, as envisioned by the draft Multi-Annual Action Plan, foresees implementation of far-reaching interventions and actions. This integration will be structured along four main areas:

- A common market for goods, services and capital;

- Free flow of skilled workforce integrated into professional and academic EU networks;

- A common digital market;

- A dynamic investment space.

One of the core points of the Trieste Summit is to entrust the Regional Cooperation Council with a role of facilitating the work of the task force and coordinating the development of the Action Plan between various regional structures and working groups, including CEFTA and others. According to (Bonomi, 2017, p.15), a major achievement of the Berlin process has been its contribution to boost the interest of the Western Balkans and EU stakeholders regarding regional cooperation. He continued that the challenge is to build on the Berlin Process and contribute to the transformation of EU enlargement policy to increase credibility and effectiveness.

Finally, it's important to summarize what is behind the idea of the EU to create the Regional Economic Area in the Western Balkans. There could be two answers to it: Firstly, the creation of REA came as a result of the current internal challenges of the EU, such as the refugee crises, BREXIT, and security and economic issues. In this context, the EU 
may have decided to shift the direct engagement from the EU institutions to the Western Balkans' regional initiatives.

Secondly, the creation of REA could be a result of an EU creative approach to coordinate and monitor tasks and reforms in the Western Balkans with the support of regional actors or regional mechanisms such as RCC, even though the role of the latter could be questioned due to its structure and the Western Balkans' history. Based on experience with other regional initiatives, as well as the current relationship between Western Balkan countries, one must conclude that the first assumption holds. The second option appears unlikely to be accepted, in particular, while taking into consideration those countries of the region could face difficulties in jointly succeeding in implementing this and similar initiatives.

\section{Results}

The study consists of three stages. In the first stage, a simple questionnaire was designed that would obtain full views of the respondents within a minimum timeframe and commitment by the respondents. In the second stage, competent respondents were identified, and the questionnaire administered in conditions whereby they could fully focus on giving their views on respective issues. The third step was to process the collected data and finally interpret the survey results. The main findings from the employed survey and descriptive statistics are as follows: around $98 \%$ of the respondents are very well informed about the Regional Economic Area in the Western Balkans. In the question whether creation of REA could be considered an adequate EU policy for the Western Balkans, only 15\% think that it is adequate, while around $85 \%$ declared that CEFTA is already present in the Western Balkans and the main challenge is not with creation of new initiatives but with implementation of the existing ones. Furthermore, when asked about the expected impact of this initiative in the Western Balkans, around $87 \%$ declared that REA will not have any significant economic impact in the Western Balkans.

Regarding political impact, around 54\% of the respondents expect that REA will have political impact in the region, whereas $46 \%$ of respondents declared that the main impact will be in supporting Regional Integration for the countries of the Western Balkans. Regarding the question whether the creation of REA will substitute the EU policy with regional policy, which respectively, will diminish EU engagement in the Western Balkans, 87\% accepted this, while 13\% still believe in EU engagement in the Western Balkans. Regarding the Regional Cooperation Council's (RCC) function and capabilities to implement the REA, around $81 \%$ of the respondents answered that RCC cannot functionalize the Regional Economic Area. Almost 31\% of the respondents answered that the RCC cannot implement the REA due to lack of institutional capacity, whereas $69 \%$ think that the RCC may fail due to political challenges of the Western Balkan countries. In the question whether the regional issues should be addressed by the EU Commission in Brussels or by the RCC, around 98\% of the respondents thought that EU Commission has much more political and institutional influence in the Balkans than the RCC and regional institutions.

\section{Conclusions}

The main conclusion of the paper is that political, economic and institutional environments in the Western Balkans are still fragile; therefore, there is a need for continuous direct support from the EU institutions, while the regional cooperation and regional institutions could be as complementary instruments. Also, two additional scenarios could be drawn from the paper:

The optimistic scenario, meaning that significant reforms will be accelerated within the framework of the Economic Regional Area for the Western Balkan countries, allowing also for achieving the European standards and economic convergence and facilitating their road towards the EU in the long run. The pessimistic scenario is that the Economic Regional Area launched by the EU and supported by regional countries could replace the idea of the European Integration for the Western Balkans as the Regional Cooperation Council cannot enhance and coordinate significantly the required reforms by the EU, therefore, it could delay the fulfillment of the tasks and reforms. Furthermore, due to BREXIT, internal issues - including monetary and fiscal reforms, migration/refugees and security challenges-it is obvious that the EU is trying to transfer the competences for the Western Balkans to the RCC.

From the Western Balkan perspective; the region is not creating any significant economic and institutional convergence; on the contrary, the region could export the negative spillover effects to the Union. Furthermore, the past has shown that regional institutions in the Western Balkans, due to their fragile democracy, cannot resolve political, economic and institutional disputes between their countries. Regarding the research question, I conclude as follows: according to the survey results, there is a conclusion that the REA was created by the EU due to its internal challenges and as a mechanism for diminished involvement of the EU in the Western Balkans rather than to find a specific model for supporting the developments in the Western Balkans 
through the RCC. Furthermore, according to respondents, the Regional Cooperation Council and other regional institutions do not have adequate capabilities to coordinate, monitor and influence the development of the regional market in the Western Balkans.

Finally, the Regional Economic Area for the Western Balkans is the second-best solution, as it does not formally halt the European Integration Process, and yet it does not create expectations for a quick integration of the Western Balkans in EU. It is therefore recommended that the EU should keep its active role in the political, economic and institutional life of the Western Balkans through the European Integration Process. Only a direct involvement of EU institutions can monitor and guarantee the success of undertaken actions by concrete instruments such as: monitoring permanently the implementation of regional initiatives, supporting the region with financial assistance, educational programs and cross-border cooperation projects.

\section{Limitations}

There are also limitations of this paper, as the REA is a new EU initiative and therefore insufficient data are available to analyze the functionalization and implementation of the REA. At this stage of developments, based on the experiences of the previous enlargement, it is very difficult to predict the future developments and effects of the REA in the Western Balkans.

\section{Further research}

In the future, it will be possible to monitor the Regional Economic Area and its impact on the reforms undertaken by Western Balkan countries. This would allow analysis of ways in which this initiative will support these countries to fulfill EU standards to follow their course towards the EU.

\section{Contribution}

Although there is a lack of data and statistics about the Regional Economic Area's effects, this paper will contribute theoretically to the literature of the European Integration and Western Balkans, based on descriptive statistics. The paper will also offer additional sources and knowledge about regional cooperation and EU enlargement of the Western Balkans.

\section{References}

Bieber, F. \& Kmezić, M. (2016). Policy brief EU enlargement in the Western Balkans in a time of uncertainty, BiEPAG, September, 2016, 1-16. www.biepag.eu.

Bonomi, M. (2017). The Western Balkans in the European Union: Perspectives of a region in Europe, a contribution to the Trieste Summit on the Western Balkans, Instituto Affari Internazionali (IAI), 17(13), 1-13.

Doring, Th. (1997). Political competencies within the EU and their significance for the Western Balkans, Journal of European Perspective for Western Balkans, 2(2), 15-33.

European Commission. (2017). Consolidated Multi-Annual Action Plan for a Regional Economic Area in the Western Balkans, Brussels, 1-18.

Erler, G. (2004). The stability pact, the stabilization and association process and the new EU strategy, Sudost Europa Mitteilungen, 4 (44), 10-20.

Grossman M. \& E. Helpman. (1995). The politics of free trade agreements, working paper. American Economic Review, 1995, vol. 85, issue 4, 667-90.

Hadjinski, B. (2010). Enhancing Regional Trade Integration in Southeast Europe, World Bank Washington DC, 3-21.

Juncker, J. (2017). Brexit, in Portal Politico. Retrieved from http://www.politico.eu/article/jean-claude-juncker-upbeat-and-ready-for-afight/

Kathuria, S. (2008). Western Balkan Integration and the EU; An agenda for trade and Growth, Washington DC, 5-27.

Moraliyska, M. (2014). Regional economic cooperation in the Western Balkans and its impact on Bulgaria, Economic Alternatives, 1(5) 1-18.

Pere, E. (2009). The significance of economic trade relation for regional integration in the West Balkans; Geografica Pannonica, 13(4), 159-165. https://doi.org/10.5937/GeoPan0904159P

Qorraj, G. (2010). Integrating the Western Balkans into the European Union: Overcoming political and economic constraints, Journal of European Perspective for Western Balkans, 2(2), 79-93.

Qorraj, G. (2016). Kosovo and Serbia between shared consequences and contested options. In Mehmeti, L\& Radeljic, B (Eds.), Economic Cooperation as a way toward Reconciliation and EU Integration for Kosovo and Serbia. (pp.195-215). Pittsburgh: University Press.

Rupnik, J. (2010). Repassing European challenges in the Balkans, Journal of European Perspective for Western Balkans, 2(2), 7-15.

Stability Pact for South East Europe. (2006). Regional cooperation in South East Europe, Annual Report for 2006, Brussels, 2006.

Stability Pact for South East Europe. (2001). Main features of MOU on trade liberalization and facilitation, Regional Table, Brussels, 2001. 
Schaefer, M. (2004). Regional cooperation as the road to the European Union: The future of the stability pact, SudostEuropa Mitteilungen, 4(44), 34-40.

Štiblar, F. (2008). Multilateral free trade agreements for Western Balkans, Journal of Southern Eastern Europe and the Balkans, 10(1), 65-92. https://doi.org/10.1080/14613190801895953

Tempera, M. (2011). Free trade agreements in Western Balkans: Cefta's achievements and problems, in portal on Central Eastern and Balkans Europe PECOB,1-18. Retrieved from http://www.pecob.eu/free-trade-agreement-western-balkans-cefta-achievementsproblems

World Bank. (2014). South East Europe regular economic report, Britlle Recovery, No. 6. Washington DC.

World Bank (2015). Coping with floods, strengthening growth, South East Europe, No. 7. Washington DC.

World Bank. (2017). The Western Balkans: Revving up the engines of growth and prosperity." Western Balkans Regional Systematic Country Diagnostics Synthesis Report, No. ACS22690. Washington DC.

\section{Author}

Gazmend QORRAJ is Associate Professor at the Faculty of Economics, University of Prishtina. He received his PhD from University of Ljubljana in 2009 and MA Economics of International Trade and European Integration in 2004 at Staffordshire University, UK and Vrije University Brussels. Since 2001, he teaches at University of Prishtina. From 2015, he has been the National Contact Point for Marie Curie actions and the European Research Council at HORIZON 2020.

\section{Proti Evropski uniji ali regionalnemu ekonomskemu območju: zahodni Balkan na razpotju}

\section{Izvleček}

Cilj tega članka je premišljati o dilemi, ali bo Evropska unija nadaljevala integracijske procese na Zahodnem Balkanu ali nasprotovala instrumentom regionalnega sodelovanja in pobudam znotraj okvira Zahodnega Balkana. Regionalno ekonomsko območje je analizirano kot bolj nedavna politika Evropske unije do preostalih držav Balkana. Ključno je analizirati idejo za regionalnim ekonomskim območjem, izhajajoč iz dveh ključnih predpostavk: prvič, vzpostavitev regionalnega ekonomskega območja je izvirala iz notranjih izzivov Evropske unije, in drugič, regionalno ekonomsko območje je nastalo kot kreativni pristop Evropske unije v prizadevanjih, da bi našla specifičen model za reforme na Zahodnem Balkanu v okviru regionalnih ustanov. $\checkmark$ članku tudi razpravljamo o regionalni trgovini in specifično o vlogi Sveta za regionalno sodelovanje pri koordiniranju teh pobud na Zahodnem Balkanu.Upoštevajoč trenutne izzive Evropske unije in težave držav Zahodnega Balkana pri obvladovanju političnih in ekonomskih problemov se lahko regionalno sodelovanje zdi kot alternativa integracijskemu procesu Evropske unije za Zahodni Balkan. Ključni sklep tega članka je, da Zahodni Balkan potrebuje neposredno podporo Evropske unije, še posebej odkar Svet za regionalno sodelovanje in drugi regionalni instrumenti ne morejo uveljaviti, podpirati in nadzorovati pobud in reform $v$ regiji.

Ključne besede: Zahodni Balkan, integracija, sodelovanje, koordinacija, regionalni, širitev 